\title{
KORELASI KADAR HBA2 DENGAN INDEKS MENTZER PADA PASIEN THALASEMIA DI RS HERMINA DEPOK
}

\author{
*Hadi Susanto ${ }^{1)}$, Diana Susanti ${ }^{1)}$ \\ ${ }^{1}$ Program Studi D III Analis Kesehatan, Fakultas Kesehatan, Universitas Mohammad Husni Thamrin \\ Correspondence author: Hadi Susanto, hadisus24@gmail.com, Jakarta, Indonesia
}

\begin{abstract}
ABSTRAK
Thalasemia merupakan penyakit keturunan yang disebabkan oleh adanya mutasi gen globin $\alpha$ atau $\beta$, yang kemudian menimbulkan kelainan sintesis Hemoglobin. Secara klinis, Thalasemia sulit dibedakan dengan anemia defisiensi besi. Indeks Mentzer adalah satu metode skrining awal yang digunakan untuk membedakan kedua hal tersebut. Tujuan penelitian ini adalah untuk mengetahui korelasi antara kadar HbA2 dengan indeks Mentzer pada pasien Thalasemia di RS Hermina Depok. Penelitian dilakukan pada bulan Mei - Agustus 2018 dengan sampel adalah 40 data hasil pemeriksaan Elektroforesa $\mathrm{Hb}$ dan indeks Mentzer pada pasien dengan diagnosa thalasemia di RS Hermina Depok. Hasil penelitian menggunakan uji korelasi Spearman menyimpulkan bahwa terdapat korelasi lemah dan berpola negatif $(\mathrm{r}=-0,078$; $p$-value $=0,631)$, yang berarti apabila nilai kadar $\mathrm{HbA} 2$ bertambah maka nilai indeks Mentzer akan berkurang, dan sebaliknya. Indeks Mentzer dihitung dari hasil hitung darah lengkap (complete blood count /CBC). Jika MCV dibagi dengan RBC kurang dari 13, maka dinyatakan sebagai Thalasemia. Tapi jika hasilnya lebih besar dari 13, maka dinyatakan sebagai anemia defisiensi besi. Pada penderita Thalasemia ditemukan adanya peningkatan kadar HbA2 dengan pembacaan menggunakan Indeks Mentzer untuk penderita Thalasemia adalah kurang dari 13. Semakin meningkat kadar $\mathrm{HbA} 2$ maka nilai indeks Mentzer akan semakin rendah dari 13.
\end{abstract}

Kata kunci: Thalasemia, HbA2, Indeks Mentzer

\section{ABSTRACT}

Thalasemia is a hereditary disease caused by the mutation of the globin $\alpha$ or $\beta$ gene, which then causes hemoglobin synthesis disorder. Clinically, Thalasemia is difficult to distinguish from iron deficiency anemia. The Mentzer Index is an initial screening method used to distinguish between the two. The purpose of this study is to find out the correlation between HbA2 levels and mentzer index in Thalasemia patients at Hermina Depok Hospital. The study was conducted in May - August 2018 with a sample of 40 data from Electrophoresis Hb examination and Mentzer index in patients with thalasemia diagnosis at Hermina Depok Hospital. The results of the study using spearman correlation test concluded that there is a weak and negatively patterned correlation ( $r$ $=-0.078 ;$-value $=0.631)$, which means that if the hba2 level value increases then the value of the Mentzer index will be reduced, and vice versa. The Mentzer index is calculated from the complete blood count (CBC). If the MCV is divided by RBC less than 13, it is declared as Thalasemia. But if the result is greater than 13, then it is expressed as iron deficiency anemia. In thalasemia patients found an increase in HbA2 levels with readings using the Mentzer Index for Thalasemia sufferers was less than 13. The higher the HbA2 level, the lower the value of the Mentzer index from 13.

Keywords: Thalasemia, HbA2, Mentzer Index

Open Journal System (OJS): journal.thamrin.ac.id

http://journal.thamrin.ac.id/index.php/anakes/issue/view/33 


\section{PENDAHULUAN}

Thalasemia pertama kali ditemukan di sekitar Laut Tengah oleh seorang dokter di Detroit USA yang bernama Thomas B. Cooley pada tahun 1925. Thalasemia adalah kelainan darah herediter yang diturunkan secara otosomal resesif akibat abnormalitas sintesis hemoglobin, terdapat satu atau lebih rantai globin yang abnormal. Haemoglobin adalah suatu protein dalam sel darah merah yang mengangkut oksigen dan nutrisi ke sel-sel lainnya dalam tubuh. Thalasemia ditandai dengan kondisi sel darah merah mudah rusak atau umurnya lebih pendek dari sel darah normal (120 hari). (Ganie, 2004).

Angka penderita thalasemia khususnya di Indonesia terus meningkat, karena minimnya pengetehuan akan penyakit Thalasemia. Penderita thalasemia di Indonesia sebanyak 9.121 pasien. Hal tersebut dilaporkan Sekretaris Diretorat Jenderal Pencegahan dan Pengendalian Penyakit Kementerian Kesehatan Asjikin Iman menyatakan jumlah penderita dan penyebaran penyakit Thalasemia di Indonesia terus meningkat dari tahun ke tahun. Berdasarkan data diatas menunjukan bahwa jumlah penderita penyakit Thalasemia di Indonesia meningkat menjadi 9.121 pasien pada 2017, paling banyak di Jawa Barat, DKI Jakarta dan Jawa Tengah. Prevalensi pembawa sifat Thalasemia banyak dijumpai pada masyarakat Cyprus, Sardinia, dan Asia Tenggara. Thalasemia merupakan penyakit hemoglobinopati herediter yang banyak dijumpai di 10 negara Asia Tenggara, meliputi 400 juta populasi masyarakat negaranegara Thailand, Laos, Kamboja, Vietnam, Myanmar, Malaysia, Indonesia, Brunei, Filipina, dan Kepulauan pasifik. (Galanello \& Origa, 2010). The Thalasemia International Federation (TIF) sejak 2015 telah menetapkan 8 Mei sebagai Hari Thalasemia International (TIF, 2015). Berdasarkan data dari Yayasan Thalasemia Indonesia, kasus Thalasemia di Indonesia terus meningkat sejak lima tahun terakhir. Pada tahun 2012 terdapat 4.896 kasus thalasemia dan pada 2017 terus meningkat menjadi 8.616 kasus thalasemia. (republika.co.id, 2018)

Diagnosis thalasemia dapat ditegakkan dengan melakukan serangkaian pemeriksaan laboratorium skrining meliputi pemeriksaan darah tepi (complete blood count/CBC), nilai eritrosit rerata seperti $\mathrm{MCV}, \mathrm{MCH}, \mathrm{MCHC}$, dan RDW. Selain itu perlu dievaluasi sediaan apus darah tepi, hitung retikulosit dan pemeriksaan elektroforesa $\mathrm{Hb}$ yang meliputi : kadar $\mathrm{HbA2}$. Selain itu diperlukan pemeriksaan cadangan besi tubuh berupa pemeriksaan ferritin, serum iron (SI) dan total iron binding capacity (TIBC). (Wirawan et al, 2011). 
Berdasarkan pedoman pelayanan medis Ikatan Dokter Anak Indonesia (IDAI) pada pemeriksaan penunjang Thalasemia, yaitu pemeriksaan laboratorium hematologi lengkap didapatkan hasil: $\mathrm{Hb}$ menurun, Indeks erirosit $(\mathrm{MCV}, \mathrm{MCH}$, dan $\mathrm{MCHC}$ menurun, $\mathrm{RDW}$ meningkat), Sediaan apus darah tepi (mikrositer, hipokrom, anisositosis, poikilositosis, sel eritrosit muda/normoblas, fragmentosit,sel target) dan Elektroforesa $\mathrm{Hb}$ (meningkatnya HbA2). (Mosca A et al, 2009).

Indeks Mentzer adalah indeks yang digunakan untuk membedakan penyakit thalasemia dengan anemia, yang ditemukan oleh William C.Mentzer di tahun 1973. Indeks ini dihitung dari hasil hitung darah lengkap (complete blood count/CBC). Jika MCV (dalam fL) dibagi dengan RBC (dalam juta per mikroliter) kurang dari 13, maka dinyatakan sebagai Thalasemia. Tapi jika hasilnya lebih besar dari 13, maka dinyatakan sebagai anemia defisiensi besi. (Ferdian BA et al, 2009).

Berdasarkan uraian diatas, peneliti tertarik untuk melakukan penelitian tentang "Korelasi kadar Hb A2 dengan indeks Mentzer pada pasien thalasemia di RS Hermina Depok“ agar didapatkan pemeriksaan yang lebih mudah, murah dan efisien.

\section{METODOLOGI PENELITIAN}

Penelitian dilaksanakan di Instalasi laboratorium RS. Hermina Depok, pada Bulan Mei sampai Agustus 2018. Populasi yang digunakan adalah pasien Rumah Sakit Hermina Depok telah menderita Thalasemia yang melakukan pemeriksaan Hematologi rutin, eritrosit, Nilai rerata-rata $(\mathrm{MCV}, \mathrm{MCH}, \mathrm{MCHC})$, Morfologi darah tepi, Serum iron, TIBC, Ferritin, Elektroforesa Hb, periode sampel Januari 2017 sampai April 2018. Sampel adalah data hasil rekam medis pemeriksaan Elektroforesa $\mathrm{Hb}$ dan indeks Mentzer pada pasien yang telah menderita Thalasemia di RS. Hermina Depok. Pada periode bulan Januari 2017 - Agustus 2018. Data yang diambil adalah data sekunder berupa hasil pemeriksaan kadar Eritrosit, MCV serta elektroforesis $\mathrm{Hb}$. Besar sampel dihitung menurut hukum rule of thumb berdasarkan data jumlah sampel minimum adalah 30 sampel, dari pasien yang terdiagnosa thalasemia melakukan pemeriksaan Hematologi rutin(Hemoglobin, hematokrit, trombosit, eritrosit, $\mathrm{MCV}, \mathrm{MCH}, \mathrm{MCHC}$, Elektroforesa $\mathrm{Hb}$ ). Jumlah tersebut telah memenuhi syarat pengambilan sampel peneliti, sehingga didapatkan jumlah sampel untuk penelitian adalah 40 orang.

Data penelitian ini diuji menggunakan persentase, yaitu perbandingan yang dinyatakan dalam deskriptif persentase (\%) berdasarkan perhitungan indeks Mentzer. Untuk mengetahui 
korelasi menggunakan SPSS-Spearman/person dan uji normalitas menggukan uji Kolmogorov-Smirnov.

\section{HASIL PENELITIAN DAN PEMBAHASAN}

\section{Hasil Penelitian}

Tabel 4.1 Distribusi Frekuensi Jenis Kelamin Pasien Thalasemia di RS Hermina Depok

\begin{tabular}{ccc}
\hline Jenis Kelamin & F & $\%$ \\
\hline Laki-Laki & 6 & $15 \%$ \\
Perempuan & 34 & $85 \%$ \\
\hline
\end{tabular}

Sumber: Data Sekunder Penelitian

Distribusi frekuensi pasien penderita Thalasemia di RS Hermina Depok menurut jenis kelamin hampir seluruhnya adalah pasien perempuan sebanyak 34 orang pasien $(85 \%)$, sedangkan pasien laki-laki sebanyak 6 orang pasien (15\%).

Tabel 4.2 Gambaran Karakteristik Individu Pasien Thalasemia di RS Hermina Depok

\begin{tabular}{cccc}
\hline Variabel & $\begin{array}{c}\text { Mean } \\
\text { Median }\end{array}$ & SD & Minimal - Maksimal \\
\hline Kadar HbA2 & 4,783 & 0,9015 & $3,3-7,4$ \\
\hline Indeks Mentzer & 5 & & \\
& 12,6172 & 2,31328 & $9,13-18,12$ \\
\hline
\end{tabular}

Sumber: Data Sekunder Penelitian

Distribusi kadar HbA2 pasien penderita Thalasemia di RS Hermina Depok didapatkan ratarata 4,783 \% dengan SD sebesar 0,9015\%. Kadar HbA2 pasien terendah adalah 3,3\% dan tertinggi adalah 7,4\%. Berdasarkan uji normalitas terhadap data kadar HbA2 dengan uji Kolmogorov-Smirnov didapatkan p-value sebesar 0,033 (p-value $<0,05$ ) sehingga disimpulkan data kadar $\mathrm{HbA} 2$ pasien penderita Thalasemia di RS Hermina Depok berdistribusi tidak normal. 
Distribusi indeks Mentzer pasien penderita Thalasemia di RS Hermina Depok didapatkan rata-rata 12,6172 dengan SD sebesar 2,31328. Indeks Mentzer pasien terendah adalah 9,13 dan tertinggi adalah 18,12. Berdasarkan uji normalitas terhadap data indeks Mentzer menggunakan uji Kolmogorov-Smirnov didapatkan p-value sebesar 0,012 ( $p$-value $<0,05)$ sehingga disimpulkan data indeks Mentzer pasien penderita Thalasemia di RS Hermina Depok berdistribusi tidak normal.

Tabel 4.3 Distribusi Indeks Mentzer Pasien Thalasemia di RS Hermina Depok Menurut Jenis Kelamin

\begin{tabular}{|c|c|c|c|c|c|c|c|}
\hline \multirow{3}{*}{ Variabel } & \multirow{3}{*}{$\begin{array}{l}\text { Kategori / } \\
\text { Kelompok }\end{array}$} & \multicolumn{4}{|c|}{ Indeks Mentzer } & \multirow{2}{*}{\multicolumn{2}{|c|}{ Total }} \\
\hline & & \multicolumn{2}{|c|}{ Thalasemia $(<13)$} & \multicolumn{2}{|c|}{ Anemia ( > 13) } & & \\
\hline & & $\mathbf{n}$ & $\%$ & $\mathbf{n}$ & $\%$ & $\mathbf{n}$ & $\%$ \\
\hline \multirow{2}{*}{$\begin{array}{c}\text { Jenis } \\
\text { Kelamin }\end{array}$} & Laki-Laki & 6 & $15 \%$ & 0 & 0 & 6 & $15 \%$ \\
\hline & Perempuan & 22 & $55 \%$ & 12 & $30 \%$ & 34 & $85 \%$ \\
\hline \multicolumn{2}{|c|}{ Total } & 28 & $70 \%$ & 12 & $30 \%$ & 40 & $100 \%$ \\
\hline
\end{tabular}

Sumber: Data Sekunder Penelitian

Berdasarkan jenis kelamin, pada 6 orang pasien laki-laki ditemukan seluruhnya berada pada ketegori Thalasemia, sedangkan pada jenis kelamin perempuan terdapat 22 orang pasien (55\%) yang berada pada kategori Thalasemia dan 12 orang $(30 \%)$ berada pada kategori anemia.

Tabel 4.4 Distribusi Indeks Mentzer Pasien Thalasemia di RS Hermina Depok Menurut Usia

\begin{tabular}{|c|c|c|c|c|c|c|c|}
\hline \multirow{3}{*}{ Variabel } & \multirow{3}{*}{$\begin{array}{l}\text { Kategori / } \\
\text { Kelompok }\end{array}$} & \multicolumn{4}{|c|}{ Indeks Mentzer } & \multirow{2}{*}{\multicolumn{2}{|c|}{ Total }} \\
\hline & & \multicolumn{2}{|c|}{$\begin{array}{c}\text { Thalasemia } \\
(<13)\end{array}$} & \multicolumn{2}{|c|}{$\begin{array}{c}\text { Anemia } \\
(>13)\end{array}$} & & \\
\hline & & $\mathbf{n}$ & $\%$ & $\mathbf{n}$ & $\%$ & $\mathrm{n}$ & $\%$ \\
\hline \multirow{5}{*}{ Usia } & $\leq 10$ tahun & 11 & $27,5 \%$ & 0 & 0 & 11 & $27,5 \%$ \\
\hline & 11-20 tahun & 1 & $2,5 \%$ & 1 & $2,5 \%$ & 2 & $5 \%$ \\
\hline & 21-30 tahun & 12 & $30 \%$ & 4 & $10 \%$ & 16 & $40 \%$ \\
\hline & $31-40$ tahun & 3 & $7,5 \%$ & 6 & $15 \%$ & 9 & $22,5 \%$ \\
\hline & $>40$ tahun & 1 & $2,5 \%$ & 1 & $2,5 \%$ & 2 & $5 \%$ \\
\hline \multicolumn{2}{|c|}{ Total } & 28 & $70 \%$ & 12 & $30 \%$ & 40 & $100 \%$ \\
\hline
\end{tabular}

Sumber: Data Sekunder Penelitian

Pada tabel 4.4 terlihat bahwa jumlah pasien penderita Thalasemia di RS Hermina Depok terbanyak berada pada kelompok usia 21 - 30 tahun berjumlah 16 orang, dengan 12 
orang (30\%) diantaranya menurut indeks Mentzer berada pada kategori Thalasemia sedangkan 4 orang lainnya (10\%) berada pada kategori Anemia.

Sementara itu, pada 11 orang pasien kelompok usia $\leq 10$ tahun ditemukan seluruhnya berada pada kategori Thalasemia menurut indeks Mentzer. Sedangkan pada kelompok $11-20$ tahun dan $>40$ tahun, memiliki distribusi pasien yang sama dimana masing-masing kelompok usia tersebut memiliki 1 orang pasien (2,5\%) yang menurut indeks Mentzer berada pada kategori Thalasemia.

Hal yang berbeda terlihat pada kelompok usia 31 - 40 tahun. Berbeda dengan kelompok usia lainnya, pada kelompok ini ditemukan lebih banyak pasien yang berada pada kategori anemia (15\%) dibandingkan dengan pada kategori Thalasemia (7,5\%).

Tabel 4.5. Korelasi Kadar HbA2 dengan Indeks Mentzer Pada Pasien Thalasemia di RS Hermina Depok

\begin{tabular}{cccc}
\hline Korelasi & n & R & p-value \\
\hline Kadar HbA2 - Indeks Mentzer & 40 & $-0,078$ & 0,631 \\
\hline
\end{tabular}

Sumber: Data Sekunder Penelitian

Analisis hubungan antara kadar HbA2 dengan indeks Mentzer pada pasien penderita Thalasemia di RS Hermina Depok dilakukan dengan menggunakan analisis non-parametrik dikarenakan data kadar HbA2 dan indeks Mentzer tidak berdistribusi normal. Uji yang dipakai adalah uji Korelasi Spearman dengan asumsi bahwa data tidak berdistribusi normal.

Pada tabel 4.5 diperoleh nilai koefisien korelasi (r) kadar HbA2 dengan indeks Mentzer sebesar -0,078 hal ini berarti bahwa antara kadar HbA2 dengan indeks Mentzer pada pasien penderita Thalasemia di RS Hermina Depok memiliki korelasi yang lemah dan berpola negatif, dimana apabila nilai kadar $\mathrm{HbA} 2$ bertambah maka nilai indeks Mentzer akan berkurang, dan sebaliknya. Hasil uji statistik didapatkan tidak ada hubungan yang signifikan antara kadar HbA2 dengan indeks Mentzer pada pasien penderita Thalasemia di RS Hermina Depok ( $p$-value $>0,05)$.

\section{Pembahasan}

Berdasarkan tabel 4.1 diketahui dalam penelitian ini jenis kelamin terbanyak pada pasien penderita Thalasemia di RS Hermina Depok adalah perempuan (85\%). Penelitian lain yang dilakukan di RSUP dr. Kariadi Semarang menemukan hasil yang sama yakni terdapat 14 
pasien (56\%) perempuan dan 11 pasien (44\%) laki-laki (Rajagukguk, Kosim, dan Tamam, 2014). Sementara itu, penelitian yang dilakukan di Poliklinik Thalasemia Anak RS Hasan Sadikin Bandung serta penelitian Safitri et.al. menemukan hasil yang berbeda, yakni proporsi pasien Thalasemia berjenis kelamin laki-laki lebih banyak dibandingkan pasien perempuan (Tejasari, Reniarti, dan Effendi, 2015; Safitri, Ernawaty, dan Karim, 2015). Hasil penelitian Ilmi et.al. melaporkan bahwa proporsi pasien laki-laki dan perempuan adalah sama (Ilmi, Hasanah, dan Bayhakki, 2014).

Thalasemia merupakan penyakit genetik yang dipengaruhi oleh faktor alel autosomal resesif, bukan penyakit yang terpaut dengan kromosom seks sehingga baik laki-laki maupun perempuan memiliki kemungkinan yang sama untuk menderita Thalasemia (Rejeki et.al., 2012). Meskipun demikian, pasien laki-laki memiliki tingkat kelangsungan hidup maksimum (maximum survival rate) yang lebih lama daripada pasien perempuan, yakni 43 tahun pada laki-laki dan 25 tahun pada perempuan (Roudbari, Soltani-Rad, dan Roudbari, 2008). Selain itu, hasil penelitian Baraz et.al. di lran juga menemukan bahwa kualitas hidup pasien ditemukan lebih rendah pada pasien perempuan (Baraz, Miladina, dan Nouri, 2016). Hal ini kemungkinan disebabkan karena pada perempuan terdapat siklus mentsruasi setiap bulannya yang menyebabkan perempuan lebih rentan untuk mengalami anemia.

Berdasarkan data pasien penderita Thalasemia di RS Hermina Depok hasil yang ditemukan pada tabel 4.2 antara lain: rata-rata kadar $\mathrm{HbA} 2$ sebesar 4,783 $\pm 0,9015 \%$; dan rata-rata Indeks Mentzer adalah 12,6172 $\pm 2,31328$.

Pemeriksaan laboratorium untuk menegakkan diagnosis Thalasemia meliputi pemeriksaan darah tepi lengkap (CBC), khususnya $\mathrm{Hb}$, nilai eritrosit rerata seperti $\mathrm{MCV}, \mathrm{MCH}, \mathrm{MCHC}$, dan RDW. Selain itu perlu dievaluasi sediaan apus darah tepi, badan inklusi $\mathrm{HbH}$ dan analisis hemoglobin yang meliputi pemeriksaan elektroforesis $\mathrm{Hb}$, kadar $\mathrm{HbA2}$, HbF. Selain itu diperlukan pemeriksaan cadangan besi tubuh berupa pemeriksaan feritin atau serum iron (SI) / total iron binding capacity (TIBC) (Ferrara et.al., 2010).

Pada penelitian ini 85\% pasien memiliki jenis kelamin perempuan. Nilai normal eritrosit pada perempuan adalah $4-5 \mathrm{juta} / \mu \mathrm{L}$, sementara pada laki-laki adalah 4,5 - 5,5 juta/ $\mu \mathrm{L}$. Pada penderita Thalasemia gangguan yang terjadi bukanlah pada jumlah eritrost namun lebih ke arah gangguan terhadap Hemoglobin dimana terjadi penurunan atau supresi total sintesis rantai polipeptida Hemoglobin, sehingga kadar Hemoglobin yang terkandung di dalam eritrosit menjadi abnormal (Urrechaga, Borque, dan Escanero, 2011). 
Mean Corpuscular Volume (MCV) adalah Volume Eritrosit Rata-Rata (VER) yaitu volume rata-rata sebuah eritrosit disebut dengan femoliter (fL). MCV dapat menunjukan apakah eritrosit normositik (80 - $95 \mathrm{fL})$, mikrositik (< $80 \mathrm{fL}$ ) atau makrositik ( $>95 \mathrm{fL})$. Apabila individu memiliki nilai MCV $<80 \mathrm{fL}$ dengan $\mathrm{Hb}$ normal dicurigai sebagai Thalasemia (AlFadhli, Al-Awaldhi, dan Al-Khaldi, 2007).

Selain $\mathrm{HbA}$ pada manusia dewasa terdapat hemoglobin pendamping (minor) yang disebut $\mathrm{HbA} 2$, dimana nilai normal HbA2 yaitu 1,5 - 3,2 \% (Hoffbrand et.al., 2005). Pada penelitian ini didapatkan rata-rata kadar $\mathrm{HbA} 2$ sebesar 4,783 $\pm 0,9015 \%$. Hal tersebut mengindikasikan adanya peningkatan terhadap kadar $\mathrm{HbA} 2$. Hal tersebut ditemukan pada penderita Thalasemia dimana pada hasil elektroforesis hemoglobin tidak ditemukannya $\mathrm{HbA}$ dan terjadi peningkatan terhadap HbA2 dan $\mathrm{HbF}$ (Mosca et.al., 2009).

Indeks Mentzer adalah metode yang digunakan untuk membedakan penyakit Thalasemia dengan anemia defisiensi zat besi, yang ditemukan oleh Mentzer di tahun 1973. Indeks ini dihitung dari hasil hitung darah lengkap (complete blood count/CBC). Jika MCV (dalam fL) dibagi dengan $\mathrm{RBC}$ (dalam juta/ $\mu \mathrm{L}$ ) kurang dari 13, maka dinyatakan sebagai Thalasemia. Tapi jika hasilnya lebih besar dari 13, maka dinyatakan sebagai anemia defisiensi besi (Ferdian, Rosdiana, dan Lubis, 2009). Hal tersebut sesuai dengan hasil penelitian ini, dimana diketahui rata-rata indeks Mentzer dalam penelitian ini adalah 12,6172 \pm 2,31328 yang termasuk dalam kategori Thalasemia. Menurut penelitian Rembulan Ayu ketepatan diagnostik ketepatan diagnosis yang tinggi dalam membedakan Thalasemia dan anemia defisiensi besi adalah indeks RDW (88,14\%) dan indeks Mentzer (86,85\%).

Menurut hasil pada tabel 4.3 berdasarkan jenis kelamin, pada 6 orang pasien laki-laki seluruhnya berada pada ketegori Thalasemia, sedangkan pada jenis kelamin perempuan terdapat 22 orang pasien (55\%) yang berada pada kategori Thalasemia dan 12 orang (30\%) berada pada kategori anemia. Terkadang penderita Thalassemia, terutama yang ringan (Thalasemia beta trait), sering salah terdiagnosa sebagai anemia defisiensi Fe. Hal ini dikarenakan gejala yang dialami penderita dan gambaran laboratorium, terutama hapusan darah yang hampir sama. Hal tersebut dapat terjadi terutama pada perempuan dikarenakan banyak faktor yang melibatkan perubahan kadar Fe dalam tubuh perempuan seperti menstruasi atau dalam masa kehamilan.

Pada tabel 4.4 dapat terlihat distribusi indeks Mentzer berdasarkan kelompok usia. Pada 11 orang pasien kelompok usia $\leq 10$ tahun ditemukan seluruhnya berada pada kategori 
Thalasemia menurut indeks Mentzer. Hal ini sesuai dengan teori yang menyatakan bahwa gejala klinis thalasemia sudah terlihat pada usia 2 tahun, tetapi penderita thalasemia baru dapat berobat pada usia 4-6 tahun karena semakin pucat sehingga mengakibatkan penderitanya memerlukan tranfusi secara berkala (Dewi, 2009). Apabila penderita Thalasemia tidak dirawat, maka hidup mereka biasanya hanya bertahan antara $1-8$ tahun (Yayasan Thalasemia Indonesia, 2008 dalam Dewi, 2009). Hasil penelitian ini sesuai dengan penelitian Jelveghari (2004) di kota Tabriz Iran yang melaporkan bahwa penderita Thalasemia terbanyak pada kelompok usia $>5$ tahun.

Hubungan kadar $\mathrm{Hb}$ A2 dengan indeks Mentzer pada penelitian ini terlihat pada tabel 4.5 dimana ditemukan adanya korelasi yang lemah dan berpola negatif $(r=-0,078)$, yang berarti apabila nilai kadar $\mathrm{Hb}$ A2 bertambah maka nilai indeks Mentzer akan berkurang, dan sebaliknya. Pada Thalasemia $\beta$ heterozigot terjadi penurunan produksi rantai globulin $\beta$, menyebabkan penurunan produksi hemoglobin A dan peningkatan kompensasi produksi rantai globin $\delta$, sehingga terjadi peningkatan $\mathrm{Hb}$ A2 (3 - $6 \%$ ). Pada $\mathrm{HbF}$ juga terjadi peningkatan kompensasi produksi rantai globulin $\gamma$, yang mengakibatkan peningkatan $\mathrm{HbF}(2$ - $8 \%$, pada $50 \%$ penderita) (Fakher dan Bijan, 2009).

Berdasarkan pemeriksaan penunjang Thalasemia, yaitu pemeriksaan laboratorium hematologi yang kemudian di konfirmasi dengan anailis Hemoglobin menggunakan elektroforesis Hemoglobin dimana tidak ditemukannya $\mathrm{Hb}$ A dan meningkatnya $\mathrm{Hb}$ A2 dan $\mathrm{Hb} F$ pada penderita Thalasemia (Mosca et.al., 2009). Sementara itu, pada pembacaan Indeks Mentzer apabila didapat nilai $<13$, maka dinyatakan sebagai Thalasemia, tapi jika hasilnya lebih $>13$, maka dinyatakan sebagai anemia defisiensi besi.

Berdasarkan penelitian Universitas Kristen Maranatha Bandung pada penderita $\beta$-Thalassemia mayor Indeks Shine \& Lal memiliki dengan menggunakan rumus MCVxMCVxMCHx0,01 didapatkan hasil sensitivitas $41,67 \%$, spesifisitas $13,79 \%$, nilai prediksi positif $37,5 \%$, nilai prediksi negatif 16\%. Indeks Mentzer memiliki sensitivitas $0 \%$, spesifisitas 86,21\%, nilai prediksi positif $0 \%$, nilai prediksi negatif 40,98\%. Indeks Shine \& Lal memiliki sensitivitas dan nilai prediksi negatif yang lebih tinggi daripada indeks Mentzer pada penderita $\beta$ Thalasemia mayor.

Berdasarkan penelitian Rembulan Ayu NP,2015 Indeks Mentzer dan RDW adalah uji yang banyak digunakan oleh para klinisi dalam skrinning awal membedakan Thalasemia dengan anemia defisiensi besi. Ketepatan diagnosis yang tinggi dalam membedakan Thalasemia dengan anemia defisiensi besi adalah indeks RDW (88.14\%), dan diikuti oleh indeks Mentzer (86,85\%). Indeks RDW (MCV/ RBC x 
RDW), bila hasilnya $\geq 220$ merupakan indikasi untuk anemia defisiensi besi dan bila hasilnya $<220$ merupakan indikasi untuk Thalassemia minor/ trait.

Penelitian yang dilakukan oleh Ghafouri et.al (2006) menunjukkan sensitivitas dan spesifisitas Indeks Mentzer yang tinggi (90,9\% dan 80,3\%) dalam mengidentifikasi kasus $\beta$ Thalasemia dan Anemia defisiensi besi. Hal serupa juga dihasilkan dalam penelitian Ehsani et.al. (2009) dimana menurut kriteria Youden yang dipakai peneliti menunjukkan bahwa sensitivitas indeks Mentzer lebih tinggi dibandingkan dengan indeks Ehsani et.al (90,1\% : $85,5 \%)$.

Penelitian Vehapoglu et.al. (2014) menunjukkan sensitivitas indeks Mentzer yang tinggi (91\%) dalam mendiagnosa kasus anemia pada 264 anak yang menderita anemia mikrotik. Dalam penelitian tersebut Vehapoglu et.al. juga mencoba membandingkan kemampuan beberapa indeks yang digunakan untuk mengidentifikasi kasus $\beta$-Thalasemia dan Anemia defisiensi besi menggunakan kriteria Youden, hasil penelitiannya adalah sebagai berikut:

Indeks Mentzer $>$ Indeks Ehsani et al. $>$ Penghitungan RBC $>$ Indeks Sirdah et.al. $>$ RDWI $>$ Indeks Srivastava $>$ Indeks Green and King $>$ Indeks England and Fraser $>$ MDHL $>$ Indeks Ricerca et.al. > Indeks Shine and Lal > MCHD. Perbedaan yang signifikan ditemukan antara hasil pengukuran tiap indeks tersebut dengan standard baku emas pengukuran $\mathrm{HbA} 2$ (p-value $<0,001)$.

Dapat disimpulkan bahwa penelitian ini sesuai dengan teori tersebut, dimana pada penderita Thalasemia ditemukan adanya peningkatan kadar $\mathrm{Hb}$ A2 dengan pembacaan menggunakan Indeks Mentzer untuk penderita Thalasemia adalah $<13$. Semakin meningkat kadar $\mathrm{Hb}$ A2 maka nilai indeks Mentzer akan semakin rendah dari 13.

\section{SIMPULAN}

Penelitian korelasi kadar $\mathrm{Hb}$ A2 dengan indeks Mentzer pada pasien Thalasemia di RS Hermina Depok memperoleh kesimpulan sebagai berikut: Persentase kategori penderita Thalasemia menurut Indeks Mentzer berdasarkan umur sebanyak 11 orang pasien kelompok usia $\leq 10$ tahun. Persentase berdasarkan jenis kelamin, pada 6 orang pasien laki-laki seluruhnya berada pada ketegori Thalasemia, sedangkan pada jenis kelamin perempuan terdapat 22 orang pasien (55\%) yang berada pada kategori Thalasemia dan 12 orang (30\%) berada pada kategori anemia. Persentase penderita Thalasemia berdasarkan karakteristik di RS Hermina Depok totalnya adalah 70\%. Korelasi kadar HbA2 dengan indeks Mentzer pada 
penelitian ini lemah dan berpola negatif $(r=-0,078)$, yang berarti apabila nilai kadar $\mathrm{HbA} 2$ bertambah maka nilai indeks Mentzer akan berkurang, dan sebaliknya.

\section{UCAPAN TERIMA KASIH}

Penulis mengucapkan terima kasih kepada RS Hermina Depok, dan Prodi D III Analis Kesehatan Fakultas Kesehatan Universitas MH Thamrin. dalam penelitian ini.

\section{DAFTAR PUSTAKA}

1. AlFadhli SM, Al-Awadhi AM, AlKhaldi D. "Validity assessment of nine discriminant functions used for the differentiation between Iron deficiency anemia and Thalasemia minor," Journal of Tropical Pediatrics. 2007;53(2):93-7

2. Baraz, S., Miladinia, M., dan Nouri, E.M. 2016. A Comparison of Quality of Life Between Adolescences with Beta Thalasemia Major andTheir Healthy Peers. International Journal of Pediatrics. 4(1): 25.

3. Dewi, S. 2009.Karakteristik Penderita Thalasemia yang Rawat Inap di Rumah Sakit Umum Pusat H. Adam Malik Tahun 2006-2008. Skripsi. Medan: USU.

4. Ehsani MA, Shahgholi E, Rahiminejad MS, Seighali F, Rashidi A. "A new index for discrimination between iron deficiency anemia and beta-Thalasemia minor: results in 284 patients," Pakistan Journal of Biological Sciences. 2009;12(5):473-5.

5. Ehsani, M.A., Shahgholi, E., Rahiminejad, M.S, Seighali, F., dan Rashidi, A. 2009.. A new index for discrimination between iron deficiency anemia and beta-thalassemia minor: results in 284 patients. Pakistan Journal of Biological Sciences. 12(5): 473-475.

6. Fakher, R. dan Bijan, K. 2009. Better differential diagnosis of iron deficiency anemia from beta-Thalasemia trait. Turkish Journal of Hematology. 26(3):138-45.

7. Ferdian, B.A., Rosdiana, N., dan Lubis, B. 2009. Impact of iron therapy on Mentzer index and red cell distribution width index in primary school children with iron deficiency anemia. Pediatric Indonesia. 49(4):195 - 196.

8. Ferrara M, Capozzi L, Russo R, Bertocco F, Ferrara D. "Reliability of red blood cell indices and formulas to discriminate between $\beta$ Thalasemia trait and iron deficiency in children," Hematology. 2010;15(2):112-15

9. Ganie, A, 2004. Kajian DNA thalasemia alpha di medan. USU Press, Medan

10. Ghafouri, M., Mostaan Sefat, L., dan Sharifi, L. 2006. Comparison of cell counter indices in differention of beta thalassemia trait and iron deficiency anemia. The Scientific Journal of Iranian Blood Transfusion Organization. 2(7): 385-389.

11. Hoffbrand, A.V., et.al. 2005. Kapita Selekta Hematologi. Edisi 4. Jakarta: EGC.

12. Ilmi, S., Hasanah, O., dan Bayhakki. 2014. Hubungan Jenis Kelamin dan Domisili dengan Pertumbuhan pada Anak dengan Thalasemia. Skripsi. Program Studi llmu Keperawatan: Universitas Riau.

13. Jelveghari, M. 2004. Demographic and Clinical Aspect in Thalassemic or Hemophilic Patients Referred to Pediatric Hospital in Tabriz City Iran. Mewells $J$.

14. Joseph Mazza (15 january 2002). Manual of clinical hematology. Lippincott Williams \& Wilkins. pp. 152-ISBN 978-0-7817-2980-2. Retrieved 4 june 2010.

15. Jurnal Penelitian:“Thalasemia".Oleh : Yuki Yunanda. Halaman 1-20. Falkutas Kedokteran Universitas Sumatra Utara. USU e-Repository®2008. 
16. Kaushansky K, Lichtman MA, Beutler E, Kipps TJ, Seligsohn U, Prchal JT. Williams Hematology. 8th ed.: McGraw-Hill Companies, Inc.; 2010. Liputan6.com, Selasa 08 May 2018 05:47 WIB, REPUBLIKA.CO.ID, 2018

17. Mosca A, Paleari R, Ivaldi G, Galanello R, Giordano PC."The role of haemoglobin A(2) testing in the diagnosis of thalassaemias and related haemoglobinopathies," Journal of Clinical Pathology. 2009;62(1):13-7.

18. Rembulan Ayu NP|Indeks RDW dan Mentzer Sebagai Uji Skrining Diagnosis Thalasemia

19. Rajagukguk, R., Kosim, M.S., dan Tamam, M. 2014. Pemberian Vitamin C Sebagai Antioksidan Terhadap Fragilitas Osmotik Eritrosit Pada F Thalasemia Mayor. Med Hosp. 2 (2): 98- 104.

20. Rejeki, D.S.S., Pradani, P., Nurhayati, N., dan Supriyanto. 2014. Model Prediksi Kebutuhan Darah Untuk Penderita Thalasemia Mayor. Jurnal Kesehatan Masyarakat Nasional. 8(7).

21. Roudbari, M., Soltani-Rad, M., dan Roudbari, S. 2008. The Survival Analysis of Beta Thalasemia Major Patients in South East of 1ran. Saudi Med J. 29(7): 1031-5.

22. Safitri, R., Ernawaty, J., dan Karim, D. 2015. Hubungan Kepatuhan Transfusi dan Konsumsi Kelasi Besi Terhadap Pertumbuhan Anak dengan Thalasemia. Jurnal Online Mahasiswa. 2(2).

23. Sirdah M, Tarazi I, Al Najjar E, Al Haddad R. "Evaluation of the diagnostic reliability of different RBC indices and formulas in the differentiation of the $\beta$-thalassaemia minor from iron deficiency in Palestinian population," International Journal of Laboratory Hematology. 2008;30(4):324- 30.

24. Siti S, Idrus A, Aru W, Marcellus S, Bambang S, Ari F. Dasar-dasar Thalasemia- Salah satu jenis Hemoglobinopati. Buku Ajar . Ilmu Penyakit Dalam. Edisi keenam Jilid II : 2014. Hal 2623-2631.

25. Takeshita, K. Thalassemia Beta. September 27, 2010. Available at : http://emedicine.medscape.com/article/206490-overview

26. Tejasari, R.K., Reniarti, L., dan Effendi, S.H. 2015. Faktor Risiko Hiperkoagulasi Pada Thalasemia Anak. Sari Pediatri. 16(6).

27. Urrechaga E, Borque L, Escanero $J F$. "The role of automated measurement of $R B C$ subpopulations in differential diagnosis of microcytic anemia and $\beta$-Thalasemia screening, " American Journal of Clinical Pathology. 2011;135(3):374-9

28. Wahidayat A. Thalasemia International Federation. [Online].; 2012 [cited 2013:120.Availablefromhttp://1stpanasian.tifconference.com/conference proceedi ngs/abstracts/thalassaemia Indonesia

29. Wirawan, 2011; Imam Budiwiyono, 2016; Weaterhall, 2016.

30. Williams Hematology. 8th ed.: McGraw-Hill Companies, Inc.; 20102.

31. Wallach , J. 2007. Interpretation of Diagnostic Test 8th Edition. Philadelphia, PA: Lippincott Williams \& Wilkins. 